Dol: https://doi.org/10.34305/nnc.v111.119

\title{
PENGALAMAN PEREMPUAN KORBAN KEKERASAN DALAM RUMAH TANGGA DI KUNINGAN : STUDI FENOMENOLOGI
}

\author{
Nia Hayati, Lia Mulyati, Neneng Arya \\ Sekolah Tinggi Ilmu Kesehatan Kuningan Garawangi \\ liamulyati@stikku.ac.id
}

\begin{abstract}
Abstrak
Angka kejadian Kekerasan dalam rumah tangga terus meningkat, dari tahun ke tahun Komnas Perempuan mencatat mengalami peningkatan yang signifikan, peningkatan tersebut belum dapat menggambarkan kondisi yang sesungguhnya, karena kejadian KDRT merupakan fenomena gunung es, masih banyak korban KDRT yang tidak melaporkan.

Penelitian ini merupakan studi fenomenologi yang mengeksplorasi pengalaman perempuan korban KDRT. Jumlah partisipan 5 orang. Pengambilan sampel dengan snowball. Proses memperoleh partisipan berdasarkan data dari Polres Kuningan. Tujuan penelitian yaitu untuk mengetahui pengalaman perempuan korban KDRT.

Hasil penelitian diperoleh data bahwa : (1) Jenis KDRT yang dialami sebagian besar partisipan berupa kekerasan fisik, 3 orang mengalami kekerasan psikis, 2 orang mengalami kekerasan ekonomi, dan 1 orang mengalami kekerasan seksual. (2) Faktor penyebab terjadi KDRT faktor ekonomi dan budaya patriarki (3) Dampak yang terjadi terhadap perempuan berupa; memar, patah, dan sampai rahimnya turun. Dampak pada anak berupa; perubahan sikap, agresif dan (4) upaya yang dilakukan berupa; melawan, diam, pasrah, lapor ke polisi, dan bercerai.

Simpulan perempuan yang mengalami KDRT sebagian besar jenis kekerasan yang di alami tidak tunggal tidak hanya kekerasan fisik yang diterima namun disertai kekerasan emosional maupun kekerasan secara finansial. Saran untuk mengurangi kejadian KDRT dapat dilakukan dengan memperbaiki pola komunikasi pasangan. Komunikasi merupakan hal mendasar dalam kehidupan berkeluarga. Komunikasi yang baik bisa menjalin hubungan yang baik pula antara suami dan istri, sebaliknya komunikasi yang tidak baik bisa menjadi penyebab terjadinya KDRT. Selain itu perlu dibina mengenai hak-hak perempuan tentang persamaan jender, diantaranya dalam segi ekonomi dan tanggung jawab.
\end{abstract}

Kata kunci : KDRT, dampak KDRT, hak-hak perempuan

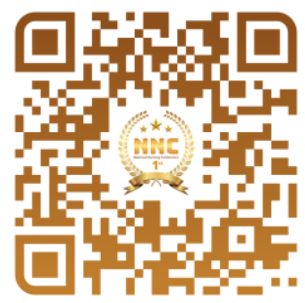

